\title{
Impact of Entrepreneurship Education on the Career Aspirations of Nigerian Para-Professional Librarians-in-Training
}

Chuma Opara Nnadozie,

Federal Polytechnic, Nekede-Owerri, Nigeria.

Pearl C. Akanwa,

Department of Library and Information Science, Imo State University, Owerri, Nigeria.

Chizoba Doris Nnadozie,

Department of Library and Information Science, Imo State University, Owerri, Nigeria.

Doi:10.5901/ajis.2012.v2n5p149

Abstract

One of the aftermaths of the on-going curriculum innovations in Nigeria's Polytechnic sector is the introduction of entrepreneurship education in all programmes/disciplines. The need to ascertain the impact of these entrepreneurship courses on the career aspirations of para-professional Librarians-in-Training (LIT) provided the prompting for this paper.A customized research instrument titled "Questionnaire on Effect of Entrepreneurship Education on Career Aspirations of Would-be Library Para-professionals" was used to elicit information from respondents selected through availability sampling from final year National Diploma (ND) and Higher National Diploma (HND) students of Library and Information Science in selected Nigerian Polytechnic. From the findings, it was evident that majority of the graduating students, who were the respondents, perceive entrepreneurship education as useful (84.6\%) and innovative (82.5\%) notwithstanding that only a few of them (8.4\%) saw the programme as being librarianship-specific. However, an overwhelming majority of the respondents agreed that these courses broadened their knowledge (50.5\%) and widened their employment options (71.2\%). It was therefore, not surprising that the result of this survey showed a paradigm shift in the career aspirations of LITs as many of the respondents preferred to be selfemployed or work in the private sector instead of waiting for the scarce traditional/conventional library-based employment. Recommendations were made to remedy certain flaws observed in the design and implementation of entrepreneurship education as part of the Library and Information Science discipline.

Keywords: Entrepreneurship Education, Library Education, Librarianship, Para-professionals, Nigeria

\section{Introduction}

There has been a proliferation of Library Schools in Nigeria in the last few decades (JAMB, 2012). This is responsible for the expanding in-take of fresh student-librarians and para-professionals at all levels of training in both public and privately-owned tertiary institutions. These prospective library employees graduate to increase the pressure on available job opportunities at their cadre in the profession. Although statistics of actual figures are unavailable, a research report posited that an increasing number of Library School graduates in Nigeria are finding themselves either unemployed, in underpaid school teaching or in dead-end jobs (Ekere and Ekere, 2012: 71). This underlines the festering graduate unemployment in Nigeria, which experts insist, has reached 'frightening proportions'. (Oteh, 2009; Obiesesan, 2010 and Ehirheme and Ekpenyong, 2012). 
Many reasons have been advanced to explain the rising level of unemployment amongst graduates, in general and Nigerian library professionals, in particular. One is the quality of practical and theoretical training to which these employees-to-be were exposed. This is exacerbated by the global economic melt-down which has constrained the ability of the public (government) and private sectors to employ and retain librariansand other categories of library workers. Experts have also hinted at a possible mismatch between the type of education received in Nigeria's tertiary institutions and the actual needs of industries and other employers of labour. (Obisesan, 2010 and Ekere and Ekere, 2012). The third, and perhaps, most poignant factor is the general orthodox orientation of Nigerian graduates, including library professionals, to depend on paid employment upon graduation rather than use their training and exposure to create jobs and allied economically-viable businesses.

The introduction of entrepreneurship education by the Federal Government of Nigeria represents one of the concrete efforts to stem the tide of rising graduate unemployment in the country. Writing on entrepreneurship education, Anyanwu, Obichere and Ossai-Onah (2012:226) explained that "it is the process of inculcating the knowledge of creating value by pooling together a unique package of resources to exploit an opportunity". As presently conceptualized, entrepreneurship education is implemented in Nigerian tertiary educational institutions to equip the undergraduate with business skills that would make them self-employed rather than job seekers, at graduation. Based on the understanding that entrepreneurship education will free the enterprising and innovative spirit of the benefitiaries, the Federal Government of Nigeria has approved its incorporation into the curriculum of her higher education institutions. The National Universities Commission (NUC) and National Board for Technical Education (NBTE), in line with their mandates as regulators of universities and polytechnics programmes, insist that students must take and pass specific entrepreneurship courses before graduation.

The NBTE syllabus for entrepreneurial education shows that the courses are meant to cover: meaning and concept of entrepreneurship; objectives and purpose; types and key competences for entrepreneurship; how to generate business ideas; propagate, manage and evaluate business or an enterprise in Nigeria and other developing counties; history and development of Information Technology (IT) in Nigeria; investment and support agencies and their roles; as well as; business planning and succession plan (NBTE, 2007). Students of Library and Information Science (LIS) in the country's polytechnics, who would qualify to become the core of intermediate library manpower, otherwise called para-professionals, take entrepreneurial courses at the National Diploma programme (i.e. ND) and during the their Higher National Diploma (HNDII). This makes the entrepreneurship education programme to cut across the two segments of polytechnic education. No doubt, the effort and programmes to make trainee-library para-professionals employable, creative and versatile through entrepreneurship education is commendable. However, there is need to ascertain the influence and/or impact of these courses on the would-be library worker's career aspirations. This leads to the specific question: what is the trainee-library para-professionals' view on the possibility of operating their own business ventures instead of waiting for paid employment upon graduation? These last two sentences represent the thrust of this paper.

\section{Objectives and Significance of the Paper}

This paper examined the influence of entrepreneurship education on the career choices of trainee paraprofessional Librarians-in-Training in selected polytechnics in Nigeria. In order to achieve this general objective, the following specific objectives were developed, to;

1. find out the respondents' knowledge of available career opportunities in librarianship;

2. identify respondents' career aspirations before taking the entrepreneurship courses;

3. ascertain the reasons for respondents career preferences after the entrepreneurial studies;

4. find out respondents' general perception of entrepreneurship education; 
5. highlight the impact of entrepreneurship education on students' career choices.

Several factors make a presentation of this nature very significant. Foremost of these is the fact that there are, relatively, few studies on the career aspirations of para-professional Librarians-in-Training in Nigeria. This report will therefore go a long way in filling this gap. Since polytechnic-trained library professionals enjoy a, somewhat, subordinate role in ranking and practice relative to their university-trained counterpart, it is also necessary to find out the effect of the entrepreneurial education courses introduced by NBTE for Library and Information Science (LIS) programme on the career aspirations and preferences of benefiting students. Similarly, researches of this nature highlight students' perception of entrepreneurship education, indicate the most preferred areas and sectors of employment aspired to and identify the factors that influence such career aspirations. Besides, available related report of career aspiration due to entrepreneurship education was based on Librarian-in-Training (LITs), in university-based Library Schools (Tella and Issa, 2012). The uniqueness of the present study is further demonstrated by the fact that it is the first reported survey of career preferences and aspirations of para-professionals Librarians-in-Training (LITs).

\section{Literature Review}

Available literature have consistently painted a gloomy picture of the unemployment situation in Nigeria. Oteh (2009) cited a World Bank Report in which only one in every ten (10) Nigerians get a job on graduation while Obisesan (2010) quoted another World Bank Research indicating that $80 \%$ of Nigerian graduates do not have the required skills to take up jobs. Ehirheme and Ekpenyong (2012) revealed that majority of Nigerian graduates who completed the mandatory National Youths Service Scheme (NYSC) in the last five (5) years remain unemployed. In the light of the foregoing, Ekere and Ekere (2012:71) posits that this situation portrays failure of the nation's entire education system and underlines an inherent mismatch between the type of education received by Nigerian graduates and the needs of government agencies, private industrial establishments and other employers of labour. The introduction of entrepreneurial education is the curriculum innovation adopted by the Nigerian authorities as one of several measures to improve the employability of graduates and reduce unemployment.

Stevenson and Jarillo (1990) explained that entrepreneurship is the process by which individuals, either on their own or inside organizations, pursue opportunities without regard to the resources they currently control. An entrepreneur, according to Anyanwu, Amadi and Oparaku (2010), takes calculated risks by investing in business opportunities and gets compensations from the risk by enjoying high profit as the result of risk-taking. The need to prepare the graduates of Nigeria's higher education institutions for the challenges and benefits of self-employment led to the introduction of entrepreneurship education. The Organization for Economic Co-operation and Development (OECD) as quoted by Aliu (2007), defined entrepreneurship education as learning directed towards developing in people, those skills, competences, understanding and attributes which equip them to be innovative, and to identify, create, initiate and successfully manage personal, community business, and work opportunities including working for themselves. In the words of Amoor (2008), entrepreneurship education will provide the students with the opportunities to identify and develop a range of skills and attributes that will be of use to creating and shaping their future by experiencing both business and work environments.

Several published researches have justified the assertion that entrepreneurship plays a vital role in creating innovation, wealth and employment. (Jones, Beynon, and Packham, 2009; Anyanwu, Amadi and Oparaka, 2010 and Ismail, et. al. 2011). Government agencies, captains of industries and other employers of labour prefer to recruit people who can make use of their talents to bring innovation and add value their workplace. Adeogun (2006) asserted that the most valued skill is the ability to access, synthesize and build information into new knowledge. It is for this reason that Aina (2006) submitted that the curriculum of Library Schools should be relevant to the immediate environment and reflect the best international practices. 
This is why experts advocate regular updating of the curriculum of LIS with emphasis on integration of entrepreneurship education in the Library and Information Science programme (Mabawonku, 2008; Anyanwu, Obichere and Ossai-Onah, 2012).

A lot of career opportunities abound for the qualified and versatile library and information science professional at all levels within the library profession. Some of these traditional library positions include acquisitions librarian, abstractor, circulation librarian, serials librarian, reference librarian, indexer, classifier, curator, archivist, and book selling/publishing (Edoka, 1991 and Anyanwu, Amadi and Oparaku, 2010). This, however, does not presuppose that the library para-professional-in-training should narrow down their job options to working in established/institutionalized libraries and information centres. Infact, diminishing job openings and exposure to entrepreneurship education should make the Library and Information Science (LIS) graduate explore the opportunities in other sectors where they can put their specialized training to their best advantage. That is why Igbeka $(2008: 29)$ charges that "librarians should work towards establishing businesses of their own”. Many other library intellectuals have written on various aspects of librarianship to which the Library Science graduate of different cadre can apply their peculiar competence and entrepreneurship education. Sellens (1980) in What Else You Can Do with a Library Degree listed many alternative uses of library education. Crawford (1988), Levine (2002), Igbeke (2008), and Ekere and Ekere (2012) discussed many aspects of information brokerage which the Library and Information Science graduate can delve into. Employment opportunities open to the person with Library Science qualification, as well as, other sectors of the economy to which the entrepreneurial training of the LIS graduate can be employed have been extensively covered in reports by Sloane (1997), Weiler (2000) and Tella and Issa, (2012).

\section{Methodology}

The survey design was chosen for this paper. This is in line with Babbie's (2004) submission that the survey approach allows the investigator to draw on a large sample that is representative of the total population. A customized research instrument entitled Questionnaire on Effect of Entrepreneurship Education on Career Aspirations of Would-be Library Para-professionals, was designed and used to collect data for the study. The queries and items in the questionnaire were adapted from earlier related published reports by Sellens (1980), Malik and Mahmood (2009) and Tella and Issa (2012).

To ensure reliability, the questionnaire was reviewed by a Chief Lecturer in LIS and pre-tested on 20 students of Federal Polytechnic, Nekede-Owerri, Nigeria. This procedure left the researchers with an elevenitem research instrument arranged in two sections. Section $A$ of the research instrument elicited essential biometric data about the respondents including name, sex, age and level of study. On the other hand, Section $B$ contained six (6) queries designed to address the core research questions and objectives of the study.

Students in the terminal classes/levels of their National Diploma (ND) and Higher National Diploma (HND) programme constituted the population of the study. Using a combination of availability and random sampling techniques, 30 copies of the questionnaire was distributed to each of these tranches (i.e. ND2 and HND2) drawn from the institutions covered in this survey. The 285 copies of the instrument (i.e. 79.2\%) used for this study were obtained from the participating institutions in the following order: Federal Polytechnic, Nekede (60); Federal Polytechnic, Auchi (51); Federal Polytechnic, Oko (54); Federal Polytechnic, Offa (40); Nasarawa State Polytechnic, Lafia (27); and Plateau State Polytechnic, Barkin Ladi (53). The returned research instruments were collated and analyzed using graphs numbered 1-6.

\section{Research Findings}

The biometric information about the respondents generated from the research questionnaire shows that 201 (70.5\%) of the participating students were females while 84 (29.5\%) were males. In terms of age 
distribution, analysis reveals that majority of the respondents (144 or 50.5\%) were within the age range of 21-30 years. This was followed by respondents between ages 18-20 years who were 75 in number (26.3\%). Those above 30 years were only 66 (23.2\%) and all were at the HND level. Further analysis indicated that the lure of entrepreneurship and financial independence was more amongst the males and those above 30 years. Most female students (187 or $65.6 \%$ ), as well as, majority of those at the ND level were more predisposed to furthering their education rather than hunt for either paid employment or establish private businesses. After this brief analysis of the biometrics of respondents, the researchers sought to ascertain the respondents' knowledge of the available career opportunities in Library and Information Science (LIS). The findings are shown in Fig. 1

Figure 1: Ranked Distribution of Five (5) Popular Career Options in Library Science.

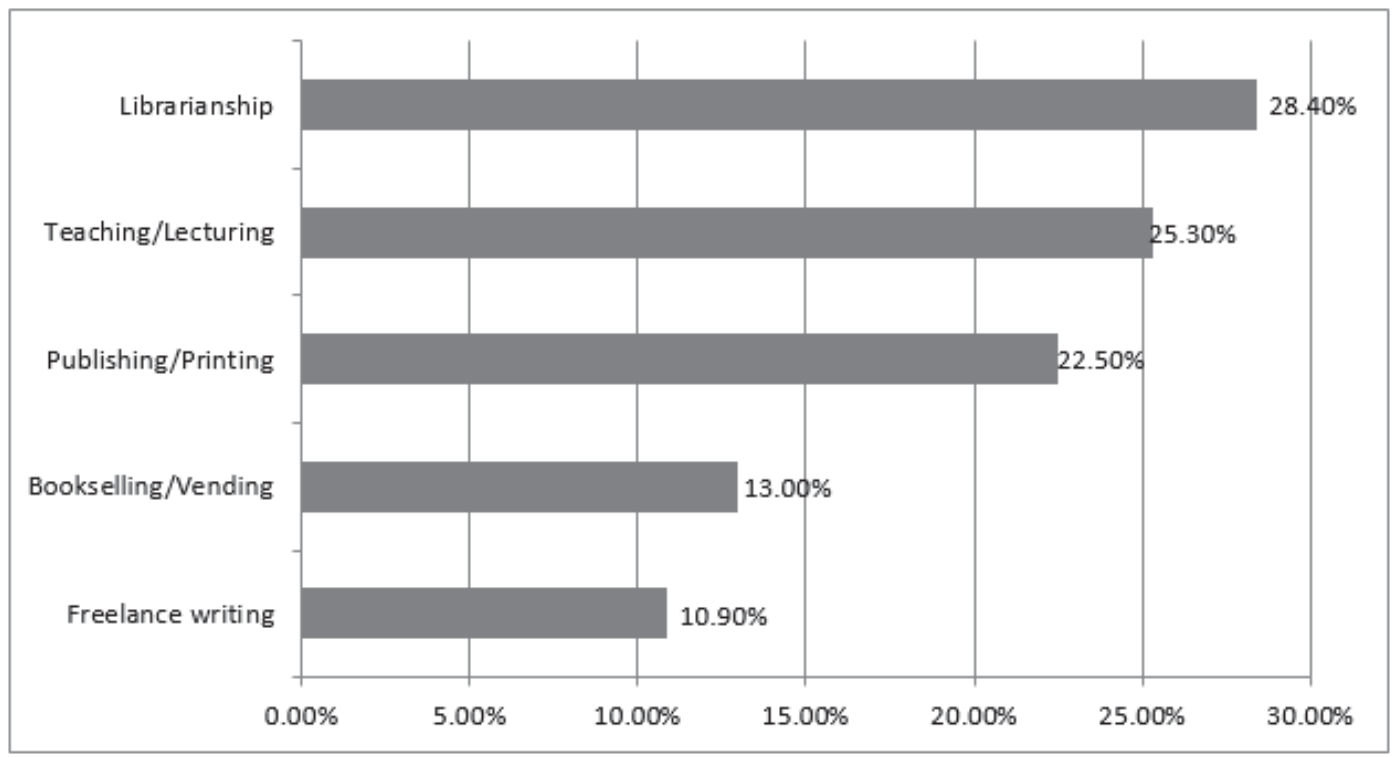

In Fig. I, librarianship was identified by majority of the respondents (81 or 28.6\%). This establishes "working in the library" as the foremost career opportunity open to the person with a Library and Information Science training, qualification and certification. The other popular career options identified by respondents were teaching/lecturing (72 or 25.3\%), printing and/or publishing (64 or 22.5\%), book selling/vending (37 or $13.0 \%$ ) and freelance writing (31 or 10.9\%). Based on the foregoing, the researchers went on to find out the respondents' career aspirations prior to their exposure to entrepreneurship education. The result is shown in Fig. 2

Figure 2: Career Aspiration of Respondents Prior to Entrepreneurship Education. 


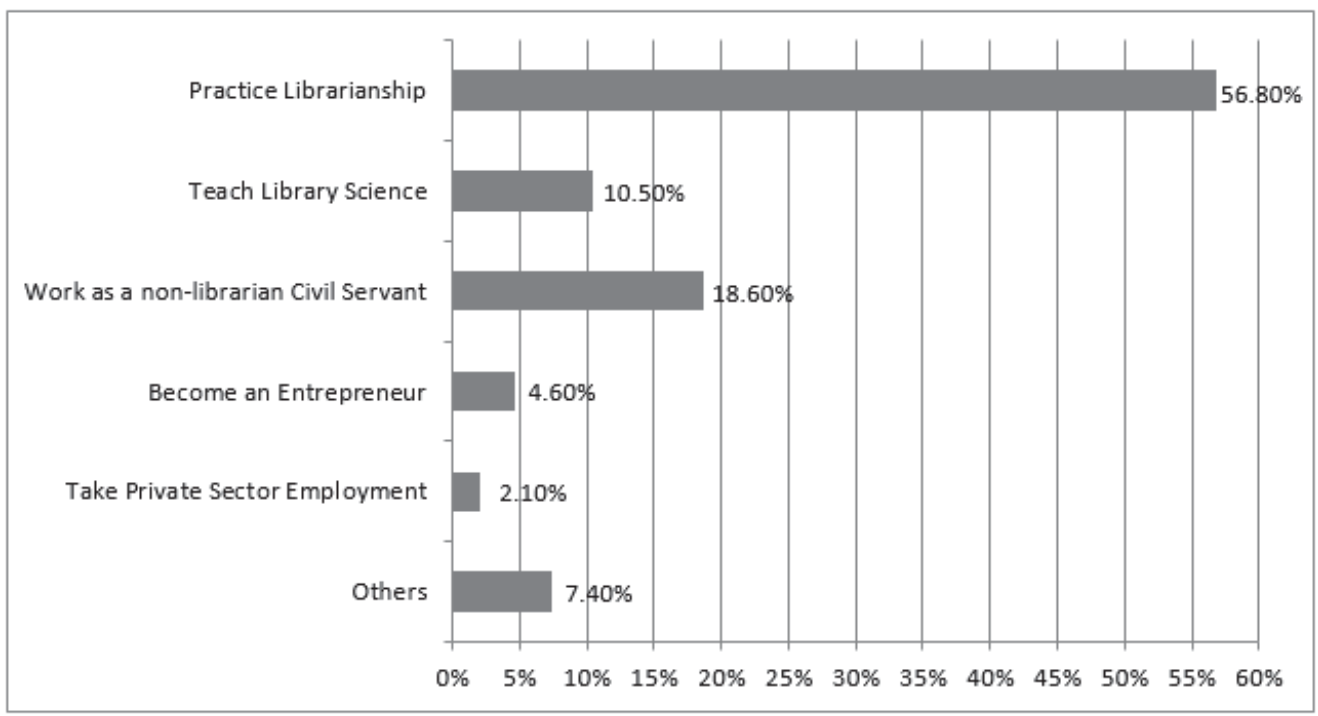

Results presented in Fig. 2 show that majority of the respondents (162 or 56.8\%) aspired to practice librarianship before their exposure to entrepreneurship education, followed by 53 respondents (18.6\%) who wanted to work as non-librarians in the civil service. Those who aspired to be lecturers of Library and Information Science were $30(10.5 \%)$. It is noteworthy that only 13 of the 285 respondents $(4.6 \%)$ wanted to own personal business while 6 of them $(2.1 \%)$ were looking forward to securing paid employment in the private sector. A total of 21 respondents $(7.4 \%)$ wanted to venture into politics, operate Non-Government Organization/Community-Based Organization (NGO/CBO) or join the armed/para-military forces, respectively. The reasons for aspiring to secure library-related jobs are presented in Fig. 3.

Figure 3: Major Reasons for Aspiring to Library-related Jobs/Employment.

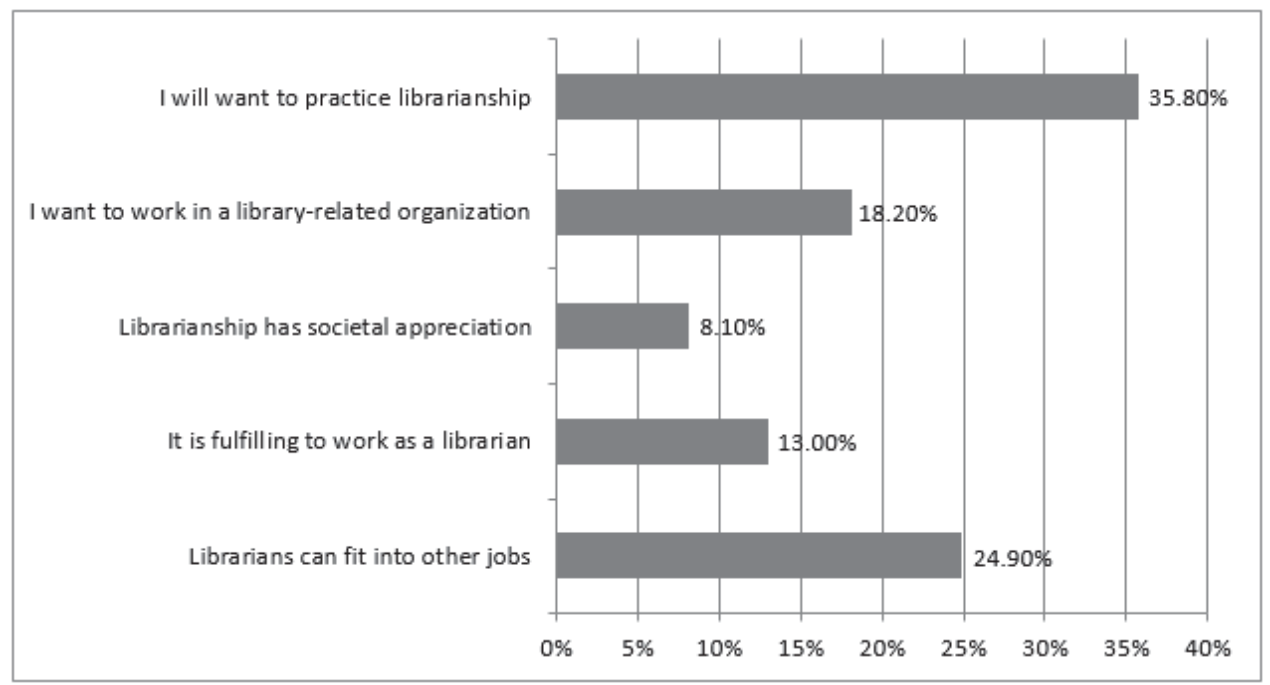


Fig. 3 presents the major reasons for which respondents initially wanted to stick to library-related employments before their exposure to entrepreneurship education. Foremost of these factors was the respondents' desire to wait to find a job in librarianship (102 or 35.8\%), closely followed by the conviction that "librarians can fit into other jobs" (71 or $24.9 \%$ ). An appreciable number of the respondents (52 or $18.2 \%$ ) wanted paid employment in allied aspects of librarianship especially, printing, publishing and book vending; while 37 respondents (13.0\%) indicated that their reason had to do with the fact that it is fulfilling to work as a librarian. The least number of respondents (23 or $8.1 \%$ ) wanted library-related jobs due to societal recognition of the profession.

Figure 4: General Perception of Entrepreneurship Education (No. = 285)

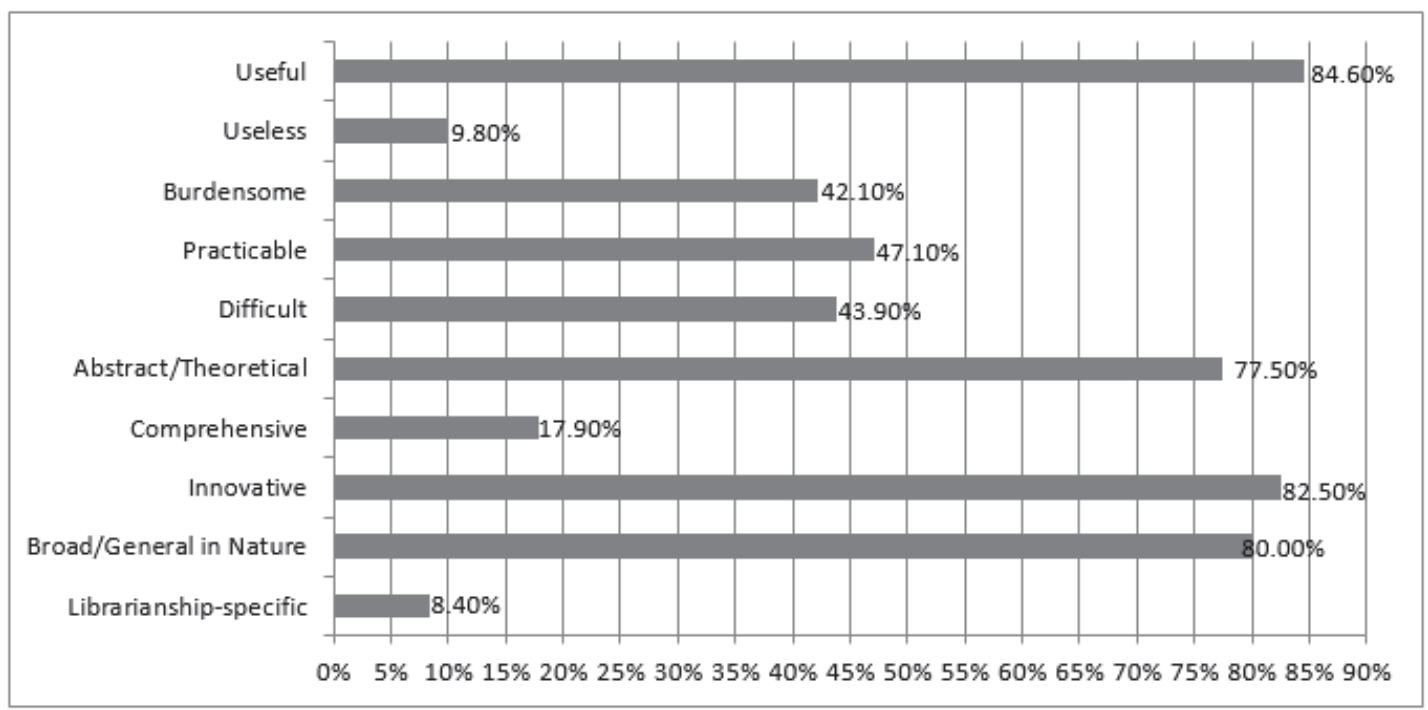

Result of respondents' perception of entrepreneurship education for the would-be library worker is presented in Fig. 4. The presentation shows clearly that an overwhelming majority (241 or $84.6 \%$ ) saw entrepreneurship education as "useful". This is followed closely by $235(82.5 \%)$ who felt that the courses are "innovative" and another 228 (80\%) who perceived entrepreneurial courses as very broad and/or general in nature. An appreciable number (221 or 77.5\%) classified the learning of entrepreneurship as very "theoretical", which provides the justification for the comparatively fewer number (24 or $8.4 \%$ ) who felt the entrepreneurship education programme is not librarianship-specific. Other elements of respondents' perception of entrepreneurship education are summarized as follows: burdensome (120 or 42.1\%), practicable (136 or $47.1 \%$ ), difficult (125 or $43.9 \%$ ) and comprehensive (51 or $17.9 \%$ ). It is instructive that as few as only 28 out of 285 respondents $(9.8 \%)$ saw entrepreneurial courses as "useless".

Figure 5: Impact of Entrepreneurship Education on Respondents (No. = 285) 


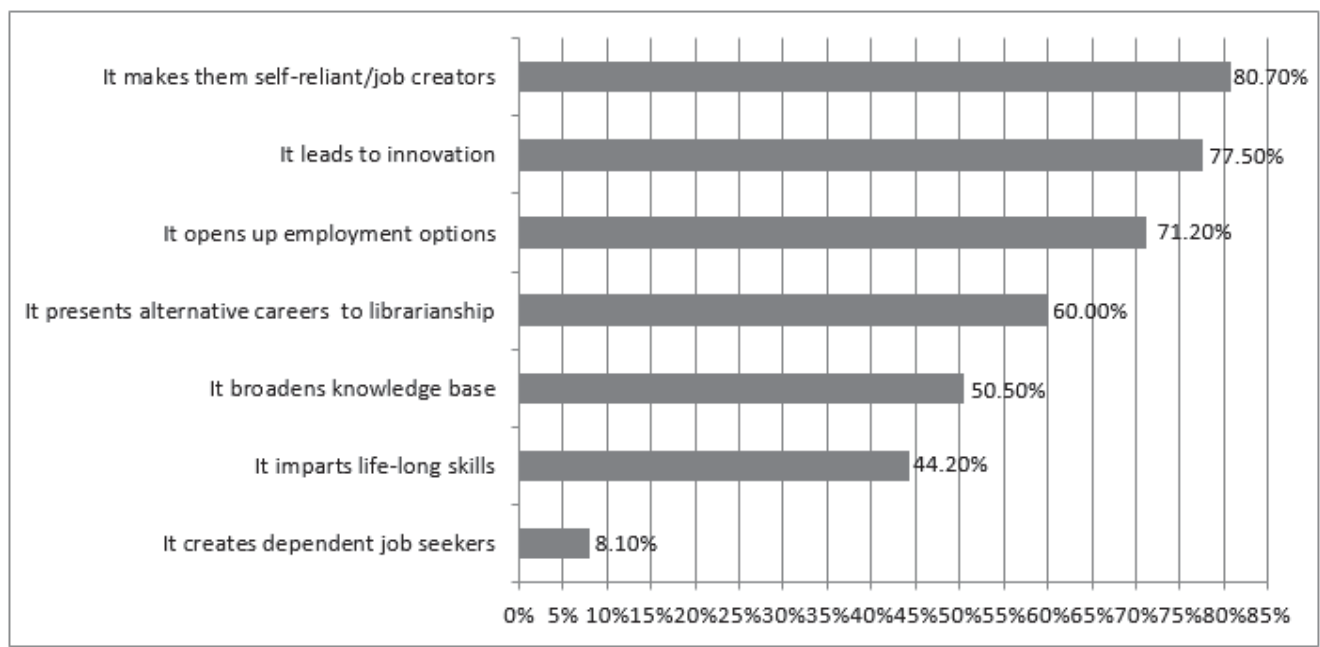

Figure 5 revealed the impact of entrepreneurship education on career aspirations. Majority of the respondents (230 or $80.7 \%$ ) indicated that it makes the graduating students self-reliant job-creators closely followed by $221(77.5 \%)$ who indicated that the courses on entrepreneurship lead to innovation. This could be responsible for the 203 respondents (71.2\%) who reported that the entrepreneurship education has widened their employment options. A total of 91 respondents $(60.0 \%)$ felt that entrepreneurship education showed them alternative careers to librarianship while 144 (50.5\%) revealed that the programme broadened their knowledge base. Respondents who felt that entrepreneurship education courses imparted life-long skills were $126(44.2 \%)$. Only 11 participants (3.9\%) reported that to entrepreneurship education makes them dependent job seekers.

Figure 6: Respondents' Career Aspirations Due to Entrepreneurship Education

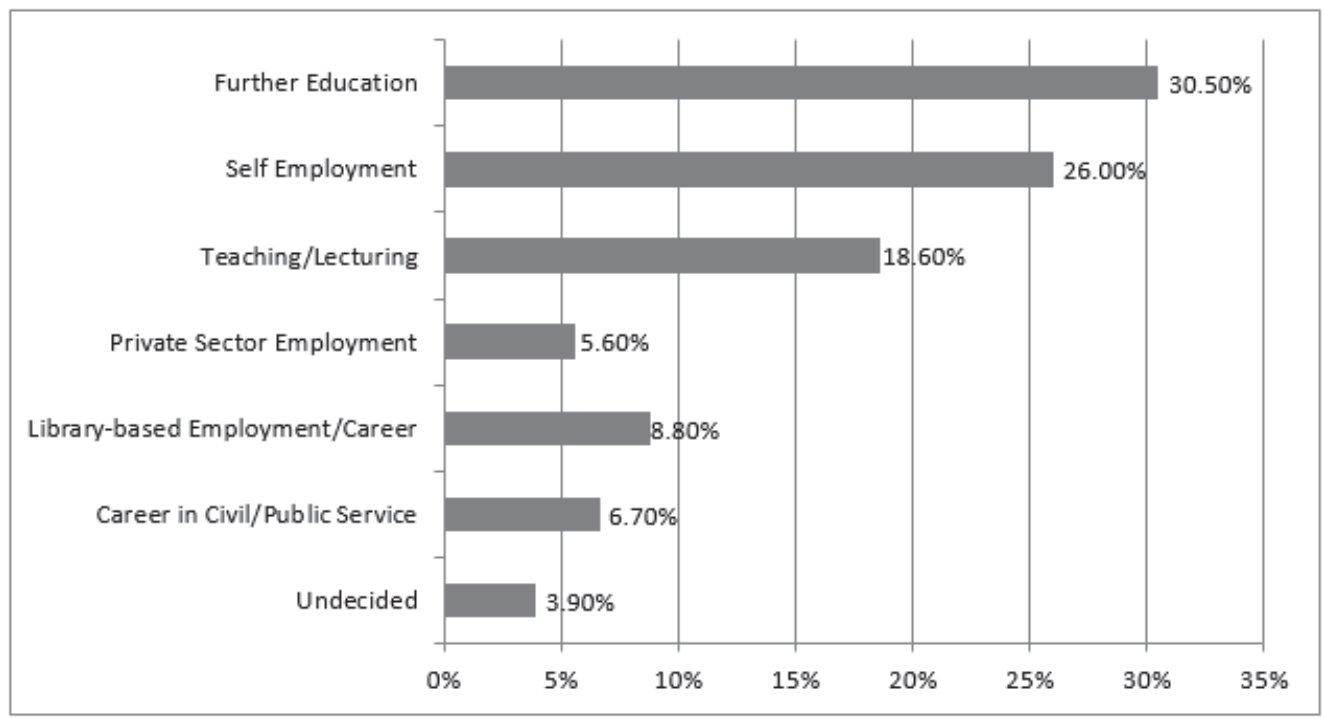


Although majority of the respondents (87 or 30.5\%) wanted to further their education at the postgraduate level rather than seek immediate employment, a good number ( 74 or $26.0 \%$ ) wanted to be selfemployed. Other career aspirations of the respondents after taking the courses in entrepreneurship education are summarized as follows: teaching (53 or 18.6\%); private sector employment (16 or 5.6\%); library-based employment (25 or $8.8 \%$ ) and employment in the civil service (19 or 6.7\%). Eleven (11) respondents (3.9\%) were non-committal as they did not take any of the options provided.

\section{Discussion of Findings}

Result shows that more than $70 \%$ of the students of LIS who took part in this study were females while males were about 29\%. This defers from the result of a related recent survey by Tella and Issa (2012) which recorded more male respondents. This study therefore hints at a likely difference in the popularity and acceptance of LIS between male and female students in North Central and South Eastern parts of Nigeria. The difference in the gender distribution of subjects of the two reports could be located in the noticeable decline in male enrolment into secondary and tertiary institutions in the Igbo-speaking (South-East) areas of Nigeria. Most of the student-respondents were between the ages of 21 and 30 years. This age distribution, partly, explains their preference for further education in Fig. 6.

Majority of the respondents were aware of the conventional jobs or career opportunities available to a person with Library and Information Science (LIS) qualification prior to the courses on entrepreneurship education. This in clear in Fig. I, where 'practice of librarianship' was identified as the foremost career opportunity by majority of the respondents. It is not surprising that "teaching/lecturing" is popular amongst the students, since most of them are aware that their core lecturers studied Library and Information Science. The appearance of publishing/printing and book selling/vending amongst the ranked list of 5 (five) popular career opportunities in LIS is understandable since the participating students have been exposes to courses in these areas in the course of their programme. The findings of this study in terms of respondents' knowledge of conventional job opportunities in librarianship tallied with related studies on the subject by Sellence (1980), Agumanu (1985) and Tella and Issa (2012).

The careers to which the respondents aspired prior to the exposure to entrepreneurship education were presented in Fig. 2. The fact that majority of these student aspired to practice librarianship or teach Library Science, cannot be surprising considering that they are studying Library and Information Science and so knowledgeable about the benefits and prospects of the profession. It is also possible that those respondents who aimed at becoming lecturers of LIS were influenced in their choice by lecturers/teachers in their department. Fig. 2 also suggest that these would-be library employees were unaware of the limited job opportunities in libraries and were still limiting their job prospects within libraries rather than explore other employment options outside librarianship. This line of reasoning is given fillip by the comparatively few number of respondents who aspired to work as non-librarians in the public civil service or secure private sector employment. It is instructive that only a few of the respondents aspired to own or manage their own private or personal businesses prior to the courses they took on entrepreneurship education.

The major reasons for which most of the students that participated in this study looked forward to securing library-related employments need to be reassessed. Foremost of these reasons as shown in Fig. 3 is the fact that most of the respondents actually wanted to practice librarianship and were ready to wait until they secure employment in libraries or allied bibliographic agencies. A situation in which almost $25 \%$ of the trainee-library workers felt they cannot fit into other jobs calls to question the quality of the teaching they received and the curriculum used by their teachers. This is on the understanding that the Nigerian tertiary education is meant to produce people who can fit into any job irrespective of the course studied (NPE, 1994). It is, however, gratifying that the introduction of entrepreneurship education is making positive impact on students of Library and Information Science (LIS). These students appreciate the inclusion of 
entrepreneurship courses in their programme. According to the findings of this study as presented in Fig. 4, entrepreneurship education is both useful and innovative although broad or general in nature and, largely, theoretical. What is referred to as "broad in nature" is explained by the very few student-respondents who saw the courses as librarianship-specific. This means that despite its usefulness, the entrepreneurship education for LIS students is not specific to Library and Information Science. As a result, the curriculum, including the entrepreneurship education, does not address extensively, the employment needs of the librarian-to-be. This aspect of the result of this study is in line with the submissions of Anyanwu, Obichere and Ossai-Onah (2012) that the present entrepreneurship education curriculum for Library and Information Science does not meet the specific need of the library and information science profession.

Entrepreneurship education has made positive impact on students of LIS. This is evident in the result of this study as shown in Fig. 5. The consensus among an overwhelming majority of these respondents is that the programme would help the LIS graduate become innovative, industrious and self-reliant. Entrepreneurship education also broadens the knowledge-base of the would-be library para-professional by making them aware of alternative uses of his/her qualification. This would ultimately widen the employment options open to such persons as the Library and Information Science graduates would not need to rely solely on library-based jobs.

Before they were introduced to entrepreneurship courses, most of the respondents restricted their career options to librarianship and allied employments. The introduction of courses on entrepreneurship education has drastically reduced the over-dependence on libraries or the civil service, for employment. Fig. 6 shows that majority of the graduating students of LIS now wish to be self-employed where they can manage their personal business ventures, while an appreciable number now wish to secure employment in the private sector organizations. Worthy of note, however, is the large number of respondents who want to further their education after graduation from the Polytechnic Library Schools. Although the urge to enhance one's academic profile may have played a part, a more plausible reason for this could be located in the apparent low rating of the polytechnic-trained library professional, which is responsible for the discrimination they experience in terms of career placement, advancement and professional recognition. These factors might have accounted for the desire of many of the respondents to this study to further their education in order to bag a university qualification and overcome the inherent professional discrimination and stagnation.

\section{Conclusion and Recommendations}

Entrepreneurship education in Nigerian tertiary education is a response to the increasing level of graduate unemployment in the country. This curriculum innovation has been extended to Library and Information Science where it is fashioned to impart business, innovative and managerial skills on the would-be LIS graduates and para-professionals. The overall objective is that upon the completion of the academic programme, and subsequent certification, the LIS graduate can establish profitable businesses and create jobs and employment for others. The inclusion of entrepreneurship education in the Library and Information Science programme of Nigerian polytechnics has made a positive impact an the career aspiration of the graduating students as most of them now hope to either establish and manage their own business ventures or seek alternative employment outside librarianship. Notwithstanding the progress made so far, certain issues need to be addressed. It is on the basis of these identified grey areas that the following recommendations are made:

1. There is need to extend entrepreneurship education at all levels of the LIS programme considering the noticeable positive impacts which entrepreneurship education has made on the career aspirations of respondents to this study. The incorporation of this curriculum innovation into the Postgraduate Diploma in Library Science (PGD/LS), Masters and Doctoral studies in LIS would further assist in making products of these programme innovative, entrepreneurial, thus, less 
dependent on library-based government employment. As a corollary, efforts should be made to review the entrepreneurship education as presently structured in order to make them more specific to the peculiar needs of the Library and Information Science profession.

2. Lecturers of LIS should be adequately exposed and knowledgeable in various aspects of entrepreneurship education. This can be achieved through attendance of conferences, workshops, seminars, symposia, short courses, etc on entrepreneurship, wealth creation and business innovations. Since entrepreneurship education has only recently been integrated into the LIS programme, it is very likely that these teachers may not have been sufficiently knowledgeable about it. The training and/or re-training being advocated would help these LIS lecturers become betterprepared to impart the skills associated with entrepreneurship and self-employment.

3. Adequate budgetary provisions should be made for the implementation of entrepreneurship education by the heads of tertiary institutions and their founders/financiers. This recommendation is on the understanding that training and retraining of lecturers for entrepreneurship education, procurement of entrepreneurship-related learning materials and installation of relevant facilities are, largely, a function of availability of funds in sufficient quantities.

4. Entrepreneurship education in LIS and other courses should be more practical and less theoretical. This means that the syllabus of entrepreneurship education in LIS and the time-table should be designed to emphasize the acquisition of practical skills. Opportunities should also be created for the LIS student to go on excursions, field trips and study visits to successful small-scale businesses, large industrial concerns and sundry businesses owned and/or managed by people with Library Science education to enable the students see entrepreneurship at work. By so doing, the LIS students would acquire valuable work-based on-the-job industrial experience, as well as, the motivation to venture into such businesses.

5. Managers of Library and Information Science (LIS) schools and heads of tertiary institutions in Nigeria should identify people to serve as entrepreneurial role-models for their students. In line with this, successful entrepreneurs, popular industrialists, small and medium scale private sector operatives and established librarians-turned-businessmen should be invited at regular intervals to interact and share their success stories and experience with Librarians-in-Training.

6. A major cause of the burgeoning employment crisis in Nigeria is the admission of both qualified and unqualified people into tertiary education institution. Establishment of technical colleges and vocational training centres is, therefore, recommended. Besides producing skillful artisans and technicians, these centres would train and assist many Nigerians to be gainfully employed. This strategy will help to discouraging those who do not have the capacity for tertiary education from fraudulently securing admission and eventually graduating to compound the employment situation in the country.

\section{References}

Adeogun, M. (2006). The Challenges of a Modern Tertiary Education System: Paradigm Shift for Educators and Information Professions in Sub-Sahara Africa. African Journal of Library, Archives and Information Science, 16 (1): 46-48.

Agumanu, J. N. (1995). Alternative Uses of Library Education in Nigeria. In: J.N. Agumanu (ed) Professional Library Education and Job utilization in Nigeria. Owerri: Ihem Devis.

Aina, L.O. (2007). Appropriate Curriculum for Library and Information Science Schools in Nigeria: The Role of Nigeria Library Association. Paper Presented at 45th National Conference/AGM of NLA held in Uyo, Akwa Ibom, Nigeria from 9th to 14th September, 20 
Aliu, S. (2008). Overview of Entrepreneurship Programme. Paper Presented during a Workshop on Entrepreneurship Development for Academic Development for Staff of Polytechnic and Monotechnics. Zone I. (South) organized by MDG/DRGS/NBTE at Yusuf Grillo Auditonum, Yaba College of Technology, 24th to 28th November 2008.

Amoor, S.S. (2008). Integrating Entrepreneurship Education into Business Education Curriculum in Nigerian University. Zaria Journal of Liberal Arts. 2 (2): 1-12. Accesses online on 20th July, 2012 at www.abu.edu.ng/publications/2011-08-24-094933_4831.dox.

Anyanwu, E.U.; Amadi, E.I. and Oparaku, D.C. (2011). Introduction to Entrepreneurship Development. Owerri: Springfield Publishers Ltd.

Anyanwu, E.U., Obichere, C.E. and Ossai-onah, V.O. (2012). Integration of entrepreneurship Education in Library and Information Science Curriculum in Nigeria. In: Aina, L.O. and Mabawonku, I. (eds). Nigerian Library Association at 50: Promoting Library and Information Science Profession for National Development and Transformation. A Compendium of Papers Presented at the 2012 AGM/Conference of the NLA held in Abuja.

Babbie, E. (2004). The Practice of Social Research. Belmont, CA: Thomason/Wadsworth.

Crawford, N.J. (1988). Information Broking: A New Career in Information Work. London: Library Association.

Edoka, B.E. (1991). Prospects of Priced Information Services in Public-funded Libraries in Nigeria. African Journal of Library, Archives and Information Science, 1 (2): 83-92.

Ehirheme, P.E. and Ekpenyong, L.E. (2012). Assessment of Opinions of Students on the implementation of entrepreneurship Education in Selected Nigeria Tertiary Institution in Edo, Delta, Lagos and Ogun States. Paper presented at an International Conference in African Indigenous research and Development Initiatives at the Goodness Convention Centre, Johnnesburg, South Africa, 24th-16th March, 2012.

Ekere, F.C. and Ekere, N. (2012). Exploring the Potentials of Information Broking in Nigeria as an Alternative Career to Librarianship. In: L.O. Aina and I. Mabawonku (eds). Nigeria Library Association at 50: Promoting Library and Information Science Profession for National Development and Transformation: Compendium of Papers presented at the 2012 AGM/Conference of NLA, July.

Igbeka, J.U. (2008). Entrepreneurship in Library and Information Services. Ibadan: Stirling-Horden.

Ismail, Z; Abdul-Kadir, S.; Akmaliah, Z. and Pihie, L. 2011). Career Aspirations among Secondary School Accounting Students. In: Selangor 2011: International Conference on Humanities, Society and Culture, IPEDR Vol. 20.

JAMB (2012). 2012 Unified Tertiary Matriculation Examinations (UTME). Abuja: Joint Admission and Matriculations Board (JAMB).

Jones, P.; Beynon, M.J. and Packham, G. (2009). Investigting the Motivation for Understanding Enterprise Education: A Carbs-Based Exposition. Retrieved online on 20th July 2012 from: htpp//www.isbe.org.UK/Content/Assets/BP09-Pauljones.pdf.

Levine, M.M. (2002). A Brief History of Information Brokering. Brokering. Accessed on 25 th July 2012 from www.e/brokering/html.

Mabawonka, I. (2008). Training for Library and Information Science Profession in Nigeria: An Overview of Recent Developments at the University of Ibadan. In: A Compendium of papers presented at the 43 AGM/Conference of NLA held at Abeokuta from 9th to 15th July, 2008.

Malik, A. and Mahmood, K. (2009). Web Search Behaviour of University Students: A Case Study at University of the Punjab. Webology, 6 (2). Accessed online on 25th July 2012 from http//www.webology.Ir/2009/V6n2/A70.html.

National Board for Technical Education-NBTE (2007). Teachers' Guide in Entrepreneurship Education for Polytechnics and Monotechnics. Kadana, Nigeria: Hamitte Consultants.

Nigeria. (1989). National Policy on Education. Lagos: Nigeria Educational Research Council (NERC).

Obisesan, M. (2010). Appointment and Management: Pay Attention to Entrepreneurial Skills. The Punch Newspaper, Tuesday, 13 th July p. 30.

Oteh, A. (2009). The Role of Entrepreneurship in Transforming the Nigerian Economy. Seventh Convocation Lecture at Igbinedion University, Okada, Nigeria.

Sellen; Betty-Carol, ed. (1980). What Else You Can Do With a Library Degree. New York: Gaylord Professional Publications.

Sloane, A. (1997). Learning with the Web: Experience of Using the World Wide Web in a Learning Environment. In: Computerized Education. Sterling: Community Bookstore. 
Stevenson, H.H. and Jarillo, J.C. (1990). A Paradigm of Entrepreneurship. Strategic Management Journal, (Special Edition), 11: 17-27.

Tella, A. and Issa, A.O. 2012). An Examination of LIS Undergraduate Students' Career Aspirations in Entrepreneurship and Self-Emplotment Opportunities in Nigeria. In: L.O. Aina and I. Mabawonku (eds). Nigeria Library Association at 50: Promoting Library and Information Science profession for National Development and transformation. A Compendium of Papers presented at the AGM/Conference of NLA held in Abuja in July, 2012.

Weiler, S. (2000). New and Updated Vendor Discounts for AIIP Members. AIIP Connections, 14 (1): 1-10 Retrieved online on 28 July 2008 from http: / /www.aiip.nig/connections. 
